Adam Ruta

Instytut Informacii Naukowej i Bibliotekoznawstwa Uniwersytet Pedagogiczny im. KEN w Krakowie e-mail: adam.z.ruta@gmail.com

\title{
Jednodniówki w systemie krakowskiej cenzury w latach 1923-1939
}

STRESZCZEnIE: Tematem artykułu jest funkcjonowanie krakowskiego systemu kontroli prasy i wydawnictw w odniesieniu do jednodniówek wydawanych lub drukowanych w tym mieście w latach 1923-1939. W oparciu o akta Sądu Okręgowego w Krakowie z lat 1919-1939, akta Sądu Powiatowego Karnego w Krakowie oraz akta Prokuratora Sądu Okręgowego w Krakowie przechowywane w Archiwum Państwowym w Krakowie autor opisuje system nadzoru nad prasą, przedstawia przyczyny wszczynania postępowań wobec wydawców jednodniówek oraz prezentuje te, które najczęściej podlegały cenzurze.

SŁowA KLUCzowe: 1923-1939, jednodniówka, Kraków, system kontroli prasy, ugrupowania lewicowe.

Eunkcjonowanie systemu kontroli prasy i wydawnictw w II Rzeczypospolitej jest od dawna przedmiotem zainteresowania badaczy. Obszernym opracowaniem na temat cenzury jest publikacja Michała Pietrzaka Reglamentacja wolności prasy w Polsce (1918-1939)ํ. Podejmowano także ten temat przy okazji badań nad prasą regionalną i lokalną, m.in. Pomorza 1963.

${ }^{1}$ M. Pietrzak, Reglamentacja wolności prasy w Polsce (1918-1939), Warszawa 
(Wiktor Pepliński)² i Wolnego Miasta Gdańska (Andrzej Romanow) ${ }^{3}$. Na gruncie krakowskim zagadnienie ograniczania wolności słowa - przede wszystkim w odniesieniu do prasy - konsekwentnie penetruje Grażyna Wrona ${ }^{4}$.

Jednodniówki, będące publikacjami z pogranicza druków zwartych i ciągłych, podlegały - jak wszystkie inne - przepisom prawa prasowego. W artykule zaprezentowano pewien wycinek działań aparatu cenzury wobec jednodniówek wydawanych lub drukowanych w Krakowie w latach 1923-1939. System nadzoru nad prasą w tym mieście tworzyły: Urząd Wojewódzki, Dyrekcja Policji, Starostwo Grodzkie w Krakowie oraz współpracujące z nim: Sąd Okręgowy i Sąd Powiatowy, Prokurator Sądu Okręgowego i Powiatowego ${ }^{5}$. Podstawą wszczęcia postępowania wobec wydawcy jednodniówki były, w zależności od rodzaju występku lub przestępstwa, odpowiednie przepisy obowiązujących wciąż austriackich aktów prawnych: „Ustawy prasowej” z 1862 r. oraz „Ustawy karnej” z 1852 r., a także „Prawa prasowego” z 1927 r. wraz z tzw. dekretem specjalnym oraz Kodeksu karnego z 1932 r. Przedmiotem nadzoru były przede wszystkim jednodniówki ugrupowań lewicowych, wydawanych zarówno w języku polskim, jak i w jidisz, które konfiskowano w całości lub w części za publikowanie artykułów antyrządowych, antyustrojowych, obraźliwych dla władz. Rzadziej podejmowano interwencje, których powodem było zamieszczenie na łamach omawianych druków treści

2 W. Pepliński, Prasa pomorska w Drugiej Rzeczypospolitej 1920-1939. System funkcjonowania i oblicze społeczno-polityczne prasy polskiej, Gdańsk 1987, s. 325-363.

3 A. Romanow, Prasa polska w Wolnym Mieście Gdańsku (1920-1939), Gdańsk 1979, s. 218-232.

${ }^{4}$ Zob. m.in. G. Wrona, „Po konfiskacie nakład drugi”: krakowska cenzura wobec „Ilustrowanego Kuriera Codziennego w latach 1918-1939, [w:] Ilustrowany Kurier Codzienny. Księga pamiątkowa w stulecie powstania dziennika i wydawnictwa 1910-1939, pod red. G. Wrony, P. Borowca, K. Woźniakowskiego, Katowice 2010, s. 148-176; taż, Lwowskokrakowski „Kurier Powszechny” (1934-1935) w systemie lokalnego nadzoru prasowego, [w:] Krakiv - L'viv. Knigi, časopisi, biblioteki XIX-XX st., t. 10, red. G. Vrona, O. Kolosovs'ka, G. Kosentka, Lviv 2011, s. 271-278; taż, „Z polecenia Pana Ministra...” Władza centralna a lokalny nadzór prasowy w latach 1918-1939 (na przykładzie Krakowa), [w:] Niewygodne dla władzy. Ograniczanie wolności słowa na ziemiach polskich w XIX i XX wieku, zbiór studiów pod red. D. Degen i J. Gzelli, Toruń 2010, s. 125-139; taż, Tygodnik „Piast” w systemie krakowskiego nadzoru prasowego (1918-1939), „Annales Universitatis Paedagogicae Cracoviensis, Studia Historicolitteraria", 2012, z. 12, s. 176-190.

5 G. Wrona, „Z polecenia Pana Ministra...”, s. 129. 
antyreligijnych lub antyżydowskich. Ścigano także występki polegające na zatajeniu nazwiska nakładcy bądź podaniu fałszywych danych. Podstawą źródłową artykułu są akta Sądu Okręgowego w Krakowie z lat 1919-1939, akta Sądu Powiatowego Karnego w Krakowie oraz akta Prokuratora Sądu Okręgowego w Krakowie przechowywane w Archiwum Państwowym w Krakowie .

Zachowane akta dotyczące jednodniówek można podzielić na dwie grupy, a mianowicie: akta spraw karnych redaktorów, wydawców i nakładców oraz akta konfiskat jednodniówek.

Akta spraw karnych zawierają bogaty materiał dowodowy zebrany zarówno przez policję państwową, Prokuratora Sądu Okręgowego, jak i Sąd Okręgowy (Wydział Karny), a więc: protokoły przesłuchań obwinionych, protokoły rozpraw, odwołania i zażalenia obwinionych, protokoły rozpraw apelacyjnych oraz - co szczególnie cenne - egzemplarze inkryminowanych druków ze śladami ingerencji cenzury - zakreślonymi fragmentami tekstów oraz przyporządkowanymi im artykułami i paragrafami odpowiednich przepisów prawnych.

Lektura akt konfiskat również dostarcza ciekawych materiałów: wniosków Starostwa Grodzkiego Krakowskiego o zatwierdzenie przez prokuratora konfiskaty, uzasadnień prokuratorskich z wnioskami do Sądu Okręgowego - niekiedy zdawkowych, podtrzymujących wniosek Starostwa, czasami zaś bardzo obszernych (najdłuższe uzasadnienie prokuratora liczyło aż 10 stron maszynopisu ${ }^{7}$ - przyp. autora); ponadto teczki zawierają tłumaczenia zakwestionowanych artykułów z języka jidysz na język polski, protokoły posiedzeń niejawnych Sądu Okręgowego (w takim bowiem trybie odbywało się zatwierdzanie konfiskat), odwołania redaktorów/wydawców oraz informacje policji o wykonaniu decyzji o konfiskacie (podawano liczbę zajętych egzemplarzy). Dołączano też wycinek z „Monitora Polskiego” zawierający wydrukowaną uchwałę Sądu w danej sprawie.

${ }^{6}$ Archiwum Państwowe w Krakowie [dalej cyt.: AP Kraków]: Akta Sądu Okręgowego w Krakowie [dalej cyt.: SO Kr], Wydział Karny, nr zespołu 29/442; Akta Sądu Powiatowego Karnego w Krakowie [dalej cyt.: SPK Kr], nr zespołu 29/445; Akta Prokuratora Sądu Okręgowego w Krakowie [dalej cyt.: PSO Kr], nr zespołu 29/467.

7 Konfiskata jednodniówki „Zew młodych robotników”, AP Kraków: Akta SO Kr, sygn. 29/442/14293. 
Procedura kontroli jednodniówek w okresie międzywojennym, niezależnie od aktualnie obowiązujących aktów prawnych, wyglądała bardzo podobnie. Zgodnie z § 17 austriackiej „Ustawy prasowej”: „Z każdego pojedynczego numeru lub zeszytu periodycznego pisma drukowego winien drukarz równocześnie z rozpoczęciem rozdawania lub rozsyłania [...] przynajmniej na 24 godziny przed rozdaniem lub rozesłaniem złożyć jeden egzemplarz u władzy bezpieczeństwa, znajdującej się w miejscu wydania, a w miejscu gdzie prokurator ma swą siedzibę, także u niego"8. Po wejściu w życie „Rozporządzenia Prezydenta Rzeczypospolitej z dnia 10 maja 1927 r. o prawie prasowym" właściciel drukarni, zgodnie z art. 7 tegoż rozporządzenia, winien niezwłocznie po odbiciu pierwszych egzemplarzy dostarczyć bezpłatnie właściwej władzy administracyjnej trzy egzemplarze obowiązkowe druku z wymienieniem liczby egzemplarzy nakładu'. Z kolei „Dekret Prezydenta Rzeczypospolitej z 21 listopada 1938 r. Prawo prasowe” stanowił w art. 5, że: „Zarządzający zakładem graficznym obowiązany jest niezwłocznie po odbiciu pierwszych egzemplarzy dostarczyć bezpłatnie: a) prokuratorowi właściwego sądu okręgowego - po trzy egzemplarze każdego czasopisma, a po jednym egzemplarzu każdego innego druku, b) właściwej powiatowej władzy administracji ogólnej - po trzy egzemplarze każdego druku"10. W Krakowie organem tym było Starostwo Grodzkie. W przypadku stwierdzenia naruszenia przepisów prawa prasowego Starostwo podejmowało decyzję o zajęciu druku, a następnie zwracało się do prokuratora Sądu Okręgowego w Krakowie z wnioskiem o zatwierdzenie decyzji. Prokurator, po przeanalizowaniu materiału dowodowego, jakim był dołączony do wniosku egzemplarz jednodniówki, kierował sprawę do Sądu Okręgowego, często z obszernym uzasadnieniem. Sąd, na posiedzeniu niejawnym, podejmował decyzję co do konfiskaty inkryminowanej jednodniówki,

8 Ustawa drukowa z 17 grudnia 1862, Dz. U. P. nr 6 z r. 1863, § 17, [w:] Ustawy karne dodatkowe wraz z ustawą drukową, oprac. J. Makarewicz, Kraków 1900.

9 Rozporzadzenie Prezydenta Rzeczypospolitej z dnia 10 maja 1927 r. o prawie prasowem, „Dziennik Urzędowy Rzeczypospolitej Polskiej” [dalej cyt: Dz.U. RP] 1927, nr 45, poz. 398, art. 7.

10 Dekret Prezydenta Rzeczypospolitej z dnia 21 listopada 1938 r. Prawo prasowe, Dz.U. RP 1938, nr 89, poz. 608, art. 5. 
powiadamiając o tym fakcie wydawcę oraz kierownika zakładu poligraficznego, w którym druk odbito ${ }^{11}$.

Jak już wspomniano, w Krakowie w pierwszej dekadzie okresu międzywojennego, tj. do roku 1927, a w praktyce do 1932 r., podstawą prawną konfiskat i spraw karnych wytaczanych wydawcom i redaktorom jednodniówek były austriackie akty prawne, czyli „Ustawa prasowa” z $1862 \mathrm{r}$. oraz „Ustawa karna” z 1852 r. ${ }^{12}$ Można wyróżnić dwie zasadnicze grupy przestępstw, a mianowicie zbrodnie zdrady stanu, zagrożone wysokimi karami więzienia i grzywny, oraz różnego rodzaju występki i przekroczenia, karane aresztem bądź grzywną. W przypadku „Ustawy karnej o zbrodniach, występkach i przekroczeniach" z 27 maja 1852 r. postawą interwencji cenzorskich były następujące paragrafy:

a) zbrodnia zdrady stanu - §58b, c „wzywanie, pobudzanie i nakłanianie do gwałtownej zmiany rządu oraz buntu i wojny domowej" - paragraf ten pięciokrotnie stanowił podstawę wszczęcia postępowania. Zastosowano go w odniesieniu do jednodniówek: „Zew Młodych”, „Zew Młodych Robotników”, „Czerwony Robociarz. Jednodniówka PPS Lewicy”, „Czerwona Warszawa” i „Związkowiec" (zob. Aneks 2) ${ }^{13}$;

b) występki:

- $\S 300$ (podburzenie do nienawiści i pogardy przeciw władzom) zastosowany w dziesięciu przypadkach. Wykorzystano go w przypadku jednodniówki „Nowy Sygnał Kolejarski” - dwie sprawy karne, „Zew Młodych”, ,Sygnał Kolejarski”, „Głos Robotnicy”, „Zew Młodych Robotników”, „Czerwony Robociarz. Jednodniówka PPS Lewicy”, ,Czerwona Warszawa”, ,Związkowiec”, ,Polska Republika Socjalistyczna" (zob. Aneks 1 oraz Aneks 2) ${ }^{14}$;

- $\S 302$ (wyzwanie, zachęcanie oraz nakłanianie do nieprzyjaznych kroków przeciw narodowościom, stowarzyszeniom religijnym,

11 Procedura ta znajduje potwierdzenie w materiale zgromadzonym w aktach spraw karnych dotyczących poszczególnych jednodniówek będących przedmiotem artykułu, zob. AP Kraków: SO Kr, Wydział Karny, nr zespołu 29/442.

12 T. J. Kotliński, Podstawy prawne ograniczania wolności słowa w ustawodawstwie prasowym dwudziestolecia międzywojennego, [w:] Niewygodne dla władzy..., s. 113-124.

13 AP Kraków: SO Kr, sygn. 14264, 14293, 14320, 14323, 14331.

${ }_{14}$ Tamże, sygn. 12898, 14379, 14264, 14273, 14291, 14293, 14320, 14323, 14331, 14420. 
klasom albo stanom społecznym, wzywanie mieszkańców państwa do wrogich sobie stronnictw) - stanowił podstawę wszczęcia postępowania w dziewięciu przypadkach. Była to jednodniówka „Nowy Sygnał Kolejarski” - dwie sprawy karne, „Zew Młodych”, „Zew Młodych Robotników”, „Czerwony Robociarz. Jednodniówka PPS Lewicy”, „Czerwona Warszawa”, „Polska Republika Socjalistyczna”, „Wiadomości Robotnicze”, „Głos Robociarza” (zob. Aneks 1 i Aneks 2) ${ }^{15}$;

- $\$ 303$ (wyszydzanie i poniżanie nauk, zwyczajów Kościoła albo stowarzyszenia religijnego ustawowo uznanego, obrażanie sługi religijnego, nieprzyzwoite zachowanie podczas obrzędów religijnych) - zastosowany tylko raz w odniesieniu do jednodniówki „Gwiazda” z 24 grudnia 1927 r. (zob. Aneks 2) ${ }^{16}$;

- $\$ 305$ (wzywanie, pobudzanie i skłanianie do czynów niemoralnych i prawem zakazanych) - ten paragraf był wykorzystywany najczęściej, bo aż dziewiętnaście razy. Stał się podstawą wszczęcia postępowania wobec jednodniówki „Głos Robotnicy” - trzy sprawy karne, „Nowy Sygnał Kolejarski” - dwie sprawy karne, „Polska Republika Socjalistyczna”, „Sygnał Kolejarski”, „Zew Młodych Robotników”, „Czerwona Warszawa”, „Związkowiec”, „Wiadomości Robotnicze”, ,Głos Robociarza”, ,Młody Robociarz. Jednodniówka PPS Lewicy”, „Życie Związkowe”, „Młody Robociarz. Jednodniówka Centralnego Wydziału Młodzieży PPS Lewicy”, „Sport na Fabryce” oraz jednodniówek w języku jidysz: „Profesjonale Stime”, „Die Sztyme”, „Der Unszlus” (zob. Aneks 1 i Aneks 2) ${ }^{17}$;

- $\S 308$ (rozsiewanie, rozszerzanie, obwieszczanie publicznie fałszywej, publiczne bezpieczeństwo niepokojącej wieści) - został użyty czterokrotnie w odniesieniu do jednodniówek „Zew Młodych”, ,,Sygnał Kolejarski”, ,Zew Młodych Robotników”, ,Związkowiec" (zob. Aneks 2) ${ }^{18}$;

\footnotetext{
15 Tamże, sygn. 12898, 14379, 14264, 14293, 14320, 14323, 14420, 14430, 1440.

16 Tamże, sygn. 14387.

17 Tamże, sygn. 12898, 14379, 12948, 13044, 14291, 14513, 14273, 14293, 14323, 14331, 14430, 14440, 14511, 14526, 14531, 14546, 14574, 14603, 14608.

18 Tamże, sygn. $14264,14273,14293,14331$.
} 
- $\S 310^{19}$ (składki albo subskrypcje w celu udaremnienia ustawowych następstw czynności karygodnych, np. na pokrycie grzywny) - również wykorzystany czterokrotnie. Były to jednodniówki „Zew Młodych”, „Sygnał Kolejarski”, „Zew Młodych Robotników”, „Związkowiec” (zob. Aneks 2) ${ }^{20}$;

- $\S 488$ (bezpodstawne, fałszywe obwinienie o czynności hańbiące albo niemoralne) - stanowił podstawę wszczęcia postępowania pięć razy. Wykorzystano go w sprawach jednodniówki „Głos Robociarza” - dwie sprawy karne, „Wiadomości Robotnicze”, „Życie Związkowe”, „Młody Robociarz. Jednodniówka Centralnego Wydziału Młodzieży PPS Lewicy" (zob. Aneks 2) ${ }^{21}$;

- $\S 491^{22}$ (obraza czci przez zrzucanie zasługujących na wzgardę przymiotów albo sposobów myślenia, wystawianie na publiczne szyderstwo) - został użyty trzykrotnie. Były to jednodniówki „Arbeter-Blat”, „Życie Związkowe”, „Młody Robociarz. Jednodniówka Centralnego Wydziału Młodzieży PPS Lewicy" (zob. Aneks 2) ${ }^{23}$. W przypadku „Ustawy prasowej” z 17 grudnia 1862 r., stosowanej nieporównanie rzadziej od „Ustawy karnej”, podstawą wszczynanych postępowań były dwa paragrafy. Najczęściej, trzy razy, wykorzystano $\S 9$ (niepodanie nazwiska drukarza, nakładcy, a w przypadku pism periodycznych wydawcy i redaktora odpowiedzialnego albo podanie fałszywych danych) ${ }^{24}$. Zastosowano go w odniesieniu do jednodniówek

${ }^{19}$ Czynności wymienione w paragrafach 308-310 traktowane były przez ustawę jako przekroczenia, jednak w przypadku popełnienia ich drukiem karane były jako występki ścisłym aresztem od jednego do sześciu miesięcy.

20 AP Kraków: SO Kr, sygn. 14264, 14273, 14293, 14331.

21 Tamże, sygn. 14430, 12915, 14440, 14526, 14531.

22 Wszelkie obrazy czci, wymienione w paragrafach 487-492, karane były jako przekroczenia aresztem od jednego do sześciu miesięcy, jeżeli jednak popełniono je w druku, wówczas - jako występki - zagrożone były karą aresztu od sześciu miesięcy do roku. Zob. § 493 Rozdziału XII, „Ustawy karnej o zbrodniach, występkach i przekroczeniach” z 27 maja 1852 r. Ustawa karna o zbrodniach, występkach i przekroczeniach z 27. maja 1852. 1. 117 d. p. p.: z uwzględnieniem zmieniających częściowo tę ustawę przepisów u. z 15. listopada 18671.131 dpp. i u. z 9 kwietnia 19101.73 dpp (Lex Offner), umieszczonych w odpowiednich miejscach tłustym drukiem w nawiasie, tłum. J. R. M., Lwów 1914.

${ }^{23}$ AP Kraków: SO Kr, sygn. 14466, 14526, 14531.

24 „Nieprzestrzeganie przepisów w paragrafie niniejszym określonych, stanowi przekroczenie, za które drukarz ponieść ma grzywnę dwudziestu do dwustu złr, świadome zaś fałszywe doniesienie jest występkiem, za który każdy winowajca ma być karanym wspomnianą grzywną a nadto aresztem od jednego tygodnia do jednego miesiąca". Zob. 
„Arbeter Kamf”, „Kolejarz” oraz „Czerwona Warszawa” (zob. Aneks 1) ${ }^{25}$. Zaledwie jeden raz użyto $§ 24$ (rozpowszechnianie pism zakazanych albo skonfiskowanych $)^{26}$. Stanowił on podstawę ocenzurowania wywieszki jednodniówki „Pikieta” (zob. Aneks 2) ${ }^{27}$.

Jednym z najczęściej przywoływanych aktów prawnych było „Rozporządzenie Prezydenta Rzeczypospolitej z dnia 10 maja 1927 roku zmieniające niektóre postanowienia ustaw karnych o rozpowszechnianiu nieprawdziwych wiadomości i o zniewagach"28, zwane też dekretem specjalnym. Rozporządzenie to, wraz z wydanym tego samego dnia dekretem prasowym ${ }^{29}$, stanowiło zunifikowane prawo prasowe. Wśród analizowanych jednodniówek aż w 20 przypadkach podstawą interwencji cenzorskiej był tenże akt prawny ${ }^{30}$. W szczególności przywoływano artykuł 1 tego rozporządzenia ${ }^{31}$.

$\S 9$ „Ustawy prasowej” z 17 grudnia 1862 r. Ustawa drukowa z 17 grudnia 1862, Dz. U. P. nr 6 z r. 1863, [w:] Ustawy karne dodatkowe wraz z ustawq drukowq, oprac. J. Makarewicz, Kraków 1900.

25 AP Kraków: SO Kr, sygn. 11277; SPK Kr, sygn. 418, 453.

${ }^{26}$ Występek ten miał być karany grzywną od pięćdziesięciu do pięciuset złr., a w razie ponownego zasądzenia także aresztem od jednego tygodnia do jednego miesiąca. Zob. $\S 24$ „Ustawy prasowej” z 17 grudnia 1862 r. Ustawa drukowa z 17 grudnia 1862, Dz. U. P. nr 6 z r. 1863, [w:] Ustawy karne dodatkowe...

27 AP Kraków: SO Kr, sygn. 16300.

${ }^{28}$ Rozporządzenie Prezydenta Rzeczypospolitej z dnia 10 maja 1927 roku zmieniajace niektóre postanowienia ustaw karnych o rozpowszechnianiu nieprawdziwych wiadomości i o zniewagach, Dz.U. RP 1927, nr 45, poz. 399, s. 559-560.

29 Rozporzadzenie Prezydenta Rzeczypospolitej z dnia 10 maja 1927 r. o prawie prasowem, Dz.U. RP 1927, nr 45, poz. 398.

30 Jednodniówki: „Nowy Sygnał Kolejarski”, „Głos Robociarza. Jednodniówka wyborcza PPS Lewicy”, „Polska Republika Socjalistyczna” (dwie sprawy karne), „Naje Gedanken” (dwie sprawy karne), „Pod Sąd Robotników”, „Głos Robotnicy” (trzy sprawy karne), „Nowy Sygnał Kolejarski”, „Wiadomości Robotnicze”, „Głos Robociarza”, „Arbeter-Blat”, „Jugend-Sztyme”, „Młody Robociarz. Jednodniówka PPS Lewicy”, „Życie Związkowe”, „Młody Robociarz. Jednodniówka Centralnego Wydziału Młodzieży PPS Lewicy”, „Czechowicki Robotnik Chemiczny”, „Sport na Fabryce” - zob. Aneks 1 i Aneks 2.

31 „Art.1. Kto rozpowszechnia wiadomość świadomie nieprawdziwą lub przekręconą, a mogącą wyrządzić szkodę Państwu lub wywołać niepokój publiczny, choćby wiadomość podawał jako pogłoskę, - będzie karany aresztem do trzech miesięcy i grzywną do pięciuset złotych, lub jedną z tych kar.

Jeśli czynu, przewidzianego powyżej, dopuszczono się w przemówieniu publicznem lub w druku, winny będzie karany - aresztem do sześciu miesięcy i grzywną do tysiąca złotych, lub jedną z tych kar. 
Latem 1932 r. uchwalony został Kodeks karny, który zastąpił akty prawne państw zaborczych obowiązujące dotychczas na terenie byłych dzielnic: austriackiej, pruskiej i rosyjskiej. Spośród artykułów Kodeksu karnego z 11 lipca 1932 r. najczęściej w odniesieniu do omawianych jednodniówek miały zastosowanie:

- art. 127 „Kto w miejscu lub w czasie zajęć urzędowych albo publicznie znieważa władzę, urząd, wojsko lub marynarkę wojenną albo ich jednostki, podlega karze aresztu do lat 2 lub grzywny." Artykuł ten wykorzystano czterokrotnie w odniesieniu do jednodniówek „Piast”, „Głos Robotniczy”, „Protest. Jednodniówka antyklerykalna” oraz „18 grudnia” (zob. Aneks 2)

- art. $154 \S 1$ „Kto publicznie nawołuje do popełnienia przestępstwa lub je pochwala, podlega karze więzienia do lat 5 lub aresztu." Tego artykułu użyto pięciokrotnie. Były to jednodniówki „Zwarty Front”, „Blok”, „Protest. Jednodniówka antyklerykalna”, „Pikieta. Jednodniówka wydziału akcji gospodarczej Stronnictwa Narodowego” oraz „18 grudnia” (zob. Aneks 2)

- art. 154 § 2 ,Jeżeli czyn, określony w $§ 1$, dotyczy zbrodni stanu, to sprawca podlega karze więzienia do lat 10.” Ten artykuł również wykorzystano pięciokrotnie. Zastosowano go do jednodniówek „Głos Robotniczy”, „Wspólny Front”, „Zwarty Front”, „Pikieta” i „18 grudnia” (zob. Aneks 2) ${ }^{34}$;

Jeśli czynu, przewidzianego w ustępie pierwszym tego artykułu, dopuszczono się publicznie lub w druku, rozpowszechniając wiadomość o działalności władz państwowych, albo o działalności urzędników państwowych lub osób wojskowych, będącej w związku z ich obowiązkami urzędowymi lub służbowymi, winny będzie karany - więzieniem od dwóch tygodni do jednego roku i grzywną od dwustu złotych do dwóch tysięcy złotych, lub jedną z tych kar,

Jeśli czynu, przewidzianego w ustępie pierwszym tego artykułu, dopuszczono się publicznie lub w druku, rozpowszechniając wiadomość o niebezpieczeństwie grożącem Państwu w jego stosunkach zewnętrznych lub wewnętrznych, zwłaszcza o niebezpieczeństwie, grożącem jego ustrojowi konstytucyjnemu lub społecznemu, winny będzie karany - więzieniem od miesiąca do lat dwóch i grzywną od trzystu złotych do trzech tysięcy złotych, lub jedną z tych kar.

Nie ulega ściganiu według powyższych postanowień, ani mylna ocena wiadomości prawdziwej, ani przekręcenie szczegółów nieistotnych w danym przypadku." Zob. Rozporządzenie Prezydenta... o zniewagach..., s. 599.

32 AP Kraków: SO Kr, sygn. 15114, 15115, 16139; PSO Kr, sygn. 353.

33 Tamże, SO Kr, sygn. 15849, 16046, 16139, 16280; PSO Kr, sygn. 353.

34 Tamże, SO Kr, sygn. 15115, 15844, 15849, 16280; PSO Kr, sygn. 353. 
- art. 170 „Kto publicznie rozpowszechnia fałszywe wiadomości, mogące wywołać niepokój publiczny, podlega karze aresztu do lat 2 i grzywny." Artykuł ten aż ośmiokrotnie stał się podstawą konfiskaty. Użyto go w odniesieniu do jednodniówek „Głos Robotniczy”, „Wspólny Front”, „Zwarty Front”, „Protest”, „Dlaczego musimy bojkotować Żydów”, „Praca Polska. Druga jednodniówka narodowych robotników Krakowa”, „Kurier Wyborczy”, „18 grudnia” (zob. Aneks 2) ${ }^{35}$;

- art. 173 „Kto publicznie lży lub wyszydza uznane prawnie wyznanie lub związek religijny, jego dogmaty, wierzenia lub obrzędy, albo znieważa przedmiot jego czci religijnej lub miejsce przeznaczone do wykonywania jego obrzędów religijnych, podlega karze więzienia do lat 3."Artykułu tego użyto trzykrotnie konfiskując jednodniówki „Piast”, „Zwarty Front” oraz „Dlaczego musimy bojkotować Żydów" (zob. Aneks 2) ${ }^{36}$.

Kwerenda archiwalna akt sądowych z lat 1923-1939 ujawniła 39 jednodniówek, wobec których wszczęto postępowanie karne bądź zarządzono konfiskatę. Wśród nich było 7 druków w języku hebrajskim, pozostałe 32 były publikacjami w języku polskim. Ogółem przeanalizowano 46 jednostek archiwalnych, w kilku bowiem przypadkach oprócz konfiskaty prokurator wnioskował o ukaranie redaktora, wydawcy bądź nakładcy druku, co skutkowało założeniem kolejnej teczki dla tego samego tytułu, ale z nową sygnaturą sprawy.

Należy dodać, że tylko w odniesieniu do 12 badanych druków podejmowano działania represyjne, opierając się na jednym artykule czy paragrafie określonego aktu prawnego. W pozostałych 27 przypadkach prokurator powoływał się na dwa lub więcej artykułów bądź paragrafów, co najczęściej związane było z dużą liczbą zakwestionowanych tekstów o rozmaitej treści, a co za tym idzie - różnych kategorii występków.

Jak już wspomniano, prawie wszystkie ocenzurowane jednodniówki były drukami o charakterze lewicowym, wydawanymi przez organizacje partyjne (Polska Partia Socjalistyczna Lewica, Niezależna Socjalistyczna

35 Tamże, SO Kr, sygn. 15115, 15844, 15849, 16139, 16226, 17375; PSO Kr, sygn. 353.

36 Tamże, SO Kr, sygn. 15114, 15849, 16226. 
Partia Pracy), związkowe (Związek Zawodowy Kolejarzy, Związek Zawodowy Robotników Przemysłu Chemicznego i Pokrewnych w Rzeczypospolitej Polskiej) i robotnicze. Wymowne i jednoznaczne były już same tytuły, m.in. „Sygnał Kolejarski”, „Głos Robotnicy”, „Zew Młodych Robotników”, „Czerwony Robociarz”, „Czerwona Warszawa”, „Związkowiec”, „Wiadomości Robotnicze” czy „Młody Robociarz”.

Jednodniówki te były konfiskowane najczęściej na mocy „Ustawy karnej" z 1852 r. z paragrafu 58 ust. b i c (zbrodnia zdrady stanu, tzn. nawoływanie do obalenia rządu, wywołania rewolucji, wojny domowej) oraz paragrafów dotyczących podburzania do nienawiści wobec władzy (§ 300), czy nakłaniania do nieprzyjaznych kroków wobec klas i stanów społecznych (§ 302). Tylko dwie jednodniówki związane były z ruchem narodowym i to one zostały skonfiskowane z powodu treści antysemickich - obie z 1937 r. („Praca Polska. Druga jednodniówka narodowych robotników Krakowa”37 oraz „Pikieta”), kolejne dwie zaś - „Gwiazda”38 oraz „Protest. Jednodniówka antyklerykalna” ${ }^{39}$ - zostały ocenzurowane z uwagi na opublikowanie artykułów obrażających religię (§ 303).

W jednodniówce „Pikieta” Prokurator Sądu Okręgowego dopatrzył się znamion występku z art. 154 Kodeksu karnego w artykule Znaczenie akcji gospodarczej Stronnictwa Narodowego. W uzasadnieniu czytamy:

W skonfiskowanym tytule oraz w skonfiskowanych ustępach powyższego artykułu zawarta jest pochwała aktów przemocy i groźby bezprawnej, dokonywanej na osobach, robiących zakupy w sklepach żydowskich i mających na celu zmuszenie tych osób do zaniechania czynienia zakupów w tych sklepach, oraz nawoływanie do popełniania tych przestępstw ${ }^{40}$.

Artykuł Dlaczego musimy bojkotować Żydów nosił znamiona występku z art. 173 i 170 Kodeksu karnego. Uzasadnienie prokuratora w tym wypadku było następujące:

\footnotetext{
37 AP Kraków: SO Kr, sygn. 16226.

38 Tamże, sygn. 14387.

39 Tamże, sygn. 16139.

40 Tamże, sygn. 16280.
} 
Autor powyższej ulotki publicznie lży i wyszydza prawnie uznane wyznanie, a mianowicie religię mojżeszową, a nadto rozpowszechnia nieprawdziwe wiadomości o stosunku ludności żydowskiej do polskiej, które są zdolne wywołać niepokój publiczny ${ }^{41}$.

Należy postawić pytanie, jak następowało orzekanie kar oraz egzekwowanie wyroków? W sprawach karnych wobec wydawców i redaktorów odpowiedzialnych oraz kierowników zakładów poligraficznych, w których odbijano inkryminowane druki sąd orzekał albo karę grzywny, albo karę aresztu z warunkowym zawieszeniem jej wykonania, lub obie kary łącznie - tak było m.in. w przypadku Maurycego Fischera właściciela i kierownika drukarni, którego skazano na tydzień aresztu i 1000000 marek polskich grzywny (po reformie Grabskiego zamienionej na $150 \mathrm{zł})^{42}$. W jednym przypadku orzeczono karę 2 miesięcy ścisłego aresztu, w apelacji zawieszonej jednak na dwa lata, z powodu - jak można przypuszczać - niezłomnej postawy wydawcy jednodniówki „Głos Robotnicy” Gabrieli Hertzówny, która - w odróżnieniu od innych obwinionych, twierdzących, że nie znali autorów zakwestionowanych tekstów - w trakcie przesłuchania oznajmiła prokuratorowi, że nie poda nazwiska autora skonfiskowanego artykułu ${ }^{43}$.

Z reguły podejmowano decyzje o zaniechaniu ścigania właścicieli bądź kierowników zakładów drukarskich z powodu braku znamion „czynu karygodnego”. Wyroki orzekano w postępowaniu uproszczonym na posiedzeniach niejawnych.

Aby uniknąć konfiskaty wydawcy, znając tryb kontroli publikacji, najczęściej dostarczali do Starostwa Grodzkiego Krakowskiego tylko egzemplarze obowiązkowe (od 2 do 5 egz.). W celu zminimalizowania ewentualnych strat finansowych wstrzymywali się z drukiem reszty nakładu do momentu zatwierdzenia (lub niezatwierdzenia) przez sąd decyzji o zajęciu jednodniówki (zob. Aneks 2).

W badanym zespole akt ani razu nie stwierdzono, by sąd zezwolił na druk zakwestionowanej przez Starostwo Grodzkie Krakowskie jed-

\footnotetext{
41 Tamże, sygn. 16226.

42 Tamże, sygn. 11277.

43 Tamże, sygn. 13044.
} 
nodniówki, natomiast zdarzało się, że sąd w przypadku części zajętych artykułów nie zatwierdzał decyzji Starostwa (2 przypadki).

Co ciekawe, w czterech przypadkach wydawcy okazali się na tyle nieprzezorni lub nieznający praktyki w zakresie cenzury, że wydrukowali pełne nakłady jednodniówek, które - rzecz jasna - zostały skonfiskowane i następnie zniszczone. Dodać trzeba, że nie były to niskie nakłady, dwukrotnie bowiem zajęto 3000 egzemplarzy (jednodniówki żydowskie „Die Sztyme”44 i „Der Unszlus”45), raz 4000 egzemplarzy („Wspólny Front”46) i także jednokrotnie 5000 egzemplarzy („Głos Robotniczy”"47).

O ile w przypadku czasopism sąd orzekając konfiskatę jednocześnie nakazywał ogłoszenie treści uchwały na łamach danego tytułu, o tyle w przypadku jednodniówek nie było to możliwe, z uwagi na ich jednorazowy, efemeryczny charakter. W każdym przypadku treść uchwały sądu publikowana była na łamach „Monitora Polskiego”, a wydatki z tytułu ogłoszeń, czyli - jak to wówczas nazywano - „koszta insercyjne”, zwracano wydawcy tegoż „Monitora”, czyli Polskiej Agencji Telegraficznej.

Podsumowując, stwierdzić trzeba, że system cenzury w Krakowie w okresie międzywojennym funkcjonował w zasadzie sprawnie ${ }^{48}$, „wyłuskując" z bieżącej produkcji wydawniczej przede wszystkim treści antypaństwowe, obraźliwe bądź krytyczne wobec władz, rzadziej antyreligijne czy antyżydowskie. Z reguły ograniczano się do konfiskat zatrzymanych druków, sporadycznie wdrażając sprawy karne przeciw redaktorom, nakładcom czy wydawcom jednodniówek.

${ }^{44}$ Tamże, sygn. 14603.

45 Tamże, sygn. 14608.

46 Tamże, sygn. 15844.

47 Tamże, sygn. 15115.

48 Czasem coś „zgrzytało” w trybach urzędniczej machiny. W 1928 r. Sąd Okręgowy w Krakowie, prowadząc sprawę jednodniówki wydanej przez Niezależną Socjalistyczną Partię Pracy, zlecił policji warszawskiej inwigilację nakładcy tego druku. Po kilku miesiącach postępowanie umorzono z powodu niemożności ustalenia miejsca pobytu podejrzanego. Zapomniano jednak powiadomić o tym fakcie stołecznych stróżów prawa. Sporą konsternację musiało zatem wywołać pismo otrzymane cztery lata później, w którym pytano krakowski sąd, czy nadal ma być prowadzona zlecona przezeń inwigilacja. Zob. AP Kraków: SO Kr, sygn. 12948. 


\title{
Jednodniówki in Krakow censorship in the period between 1923 and 1939
}

\begin{abstract}
The article raises the subject of press and publishing houses control in Krakow with reference to jednodniowka (short newspaper published occasionally for specific purpose) that was published or printed in the city of Krakow in the period of 1923 to 1939. The system of the press surveillance was composed of: Province Office, Municipal Office in Krakow as well as District Court and Regional Court, District Public Prosecutor and Regional Public Prosecutor and police. Legal proceedings were commenced on the basis of proper Austrian legal acts: the Press Act from 1862, the Penal Act from 1852 as well as press law 1927 together with, so called, special decree and penal code from 1932. Jednodniowki, published by the Left both in Polish and jidish language, were usually the subject of the surveillance. They were confiscated entirely or partly for publishing the articles that were expressing views against the government, political system or were offensive for the authorities. Publication of anti-religious and anti-Semitic articles did not result in such frequent interventions. Giving false names and data or concealing them were also the acts pursued by the police. The article's information root are acts of District Court in Krakow from the period of 1919-1939, Regional Court of Law acts as well as District Public Prosecutor's acts stored in State Archives in Krakow.
\end{abstract}

KEYWORDS: 1923-1939, jednodniowka, Krakow, left-wing parties, system of the press surveillance. 


\begin{tabular}{|c|c|c|c|c|c|}
\hline $\begin{array}{l}:= \\
\frac{\pi}{0} \\
0 \\
0 \\
\frac{0}{\pi} \\
3 \\
\frac{4}{0} \\
\frac{1}{3} \\
3\end{array}$ & 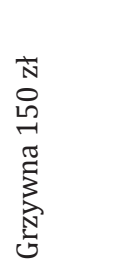 & & & 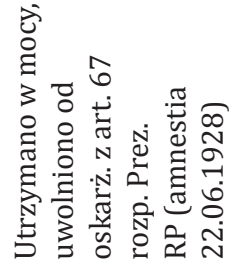 & 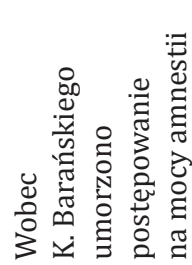 \\
\hline 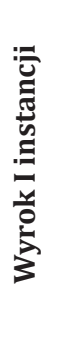 & 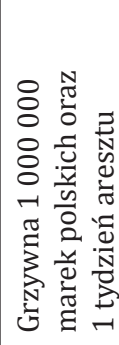 & 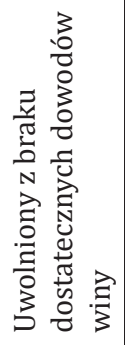 & 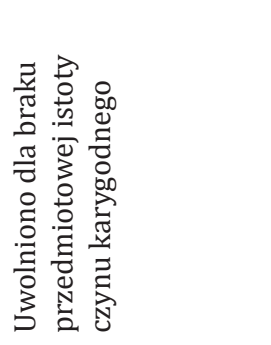 & 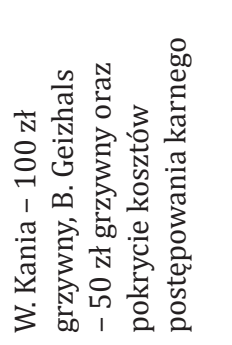 & 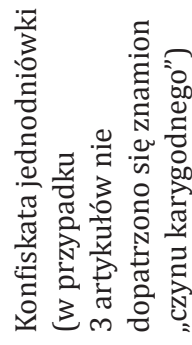 \\
\hline 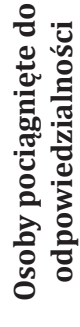 & 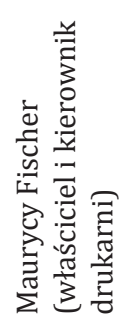 & 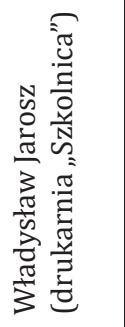 & 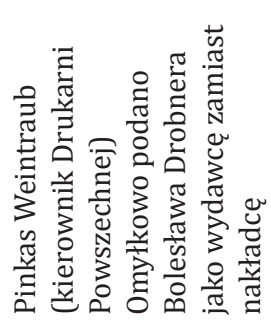 & 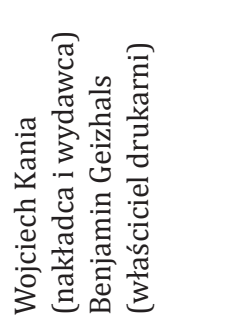 & 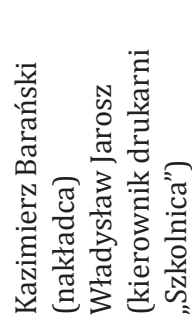 \\
\hline 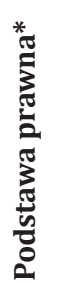 & 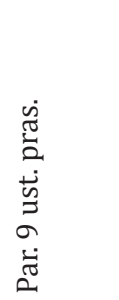 & 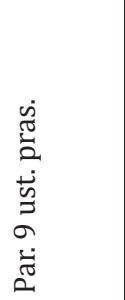 & 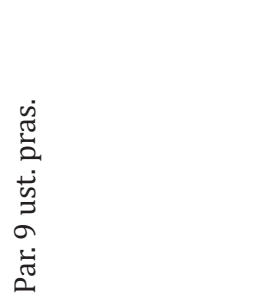 & 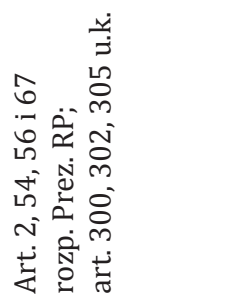 & 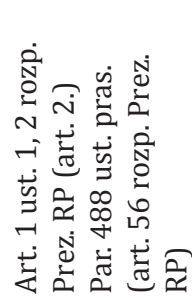 \\
\hline 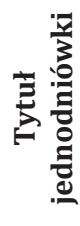 & 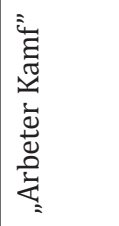 & $\begin{array}{l}\frac{N}{N} \\
\frac{\pi}{0} \\
\frac{\pi}{0} \\
\frac{1}{2} \\
=\end{array}$ & 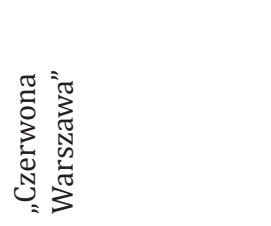 & 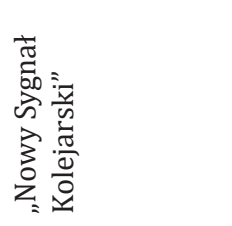 & 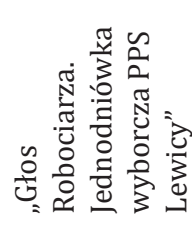 \\
\hline 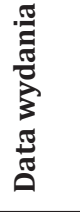 & 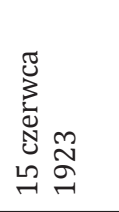 & 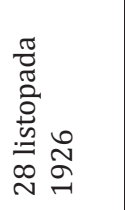 & $\underset{\sim}{\sim}$ & 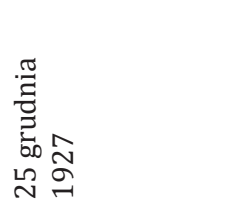 & 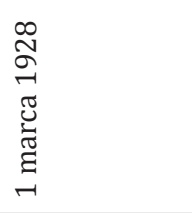 \\
\hline
\end{tabular}




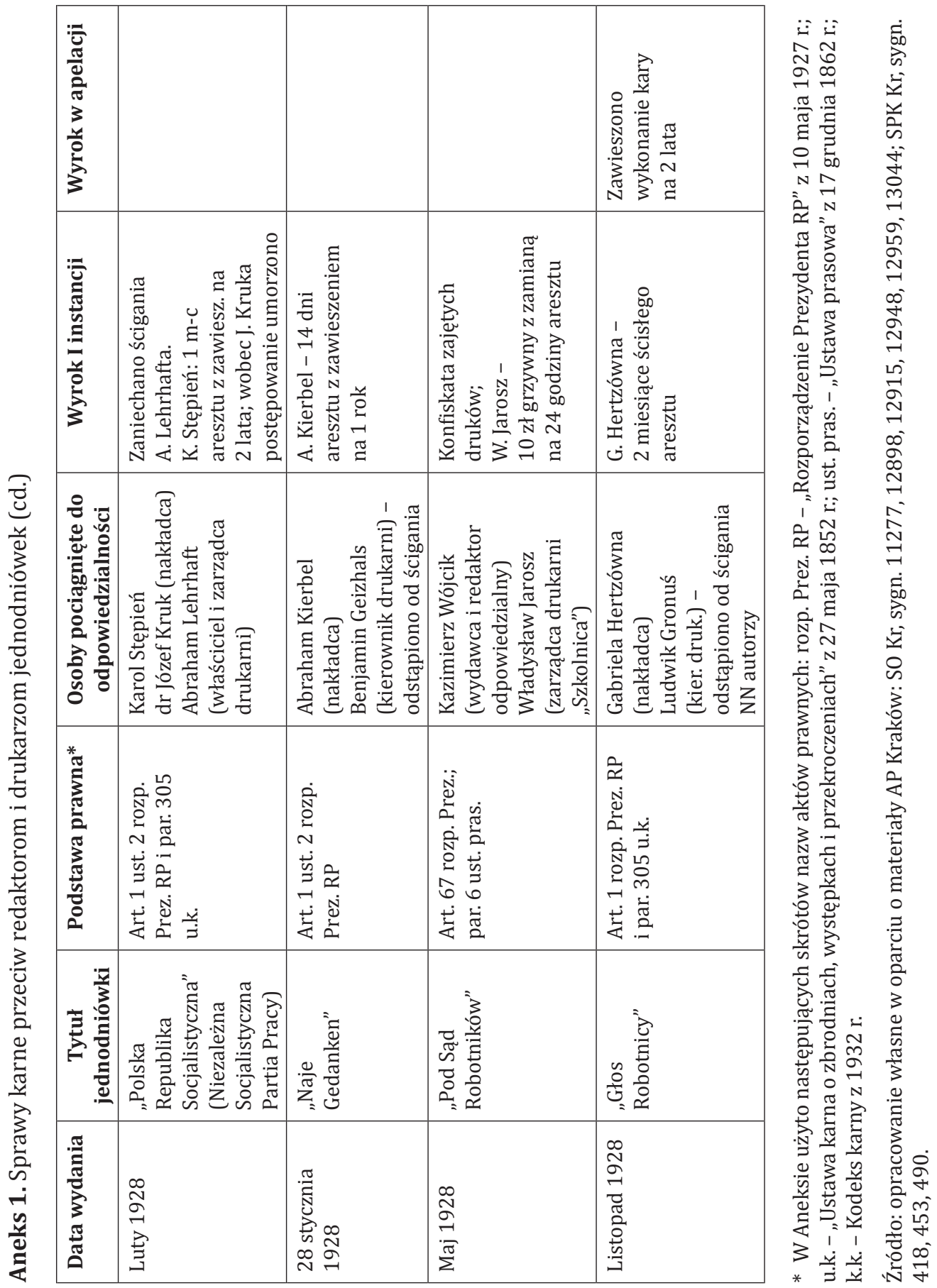




\begin{tabular}{|c|c|c|c|c|c|c|c|c|}
\hline 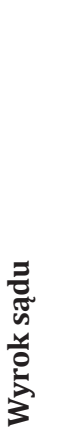 & 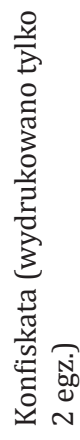 & 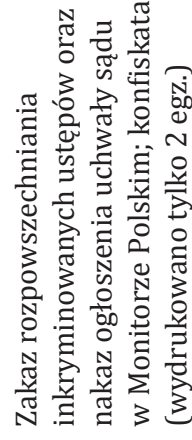 & 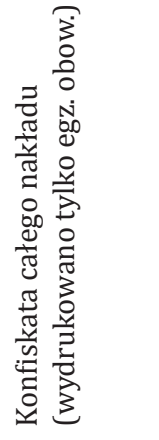 & 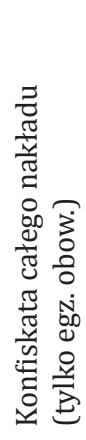 & 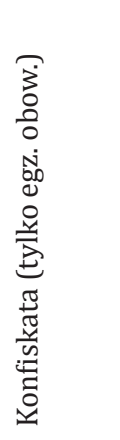 & 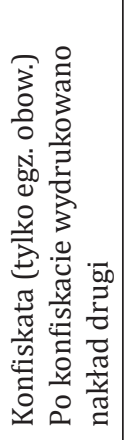 & 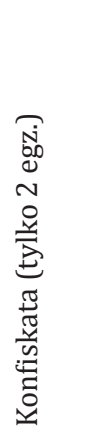 & 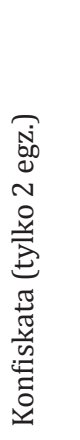 \\
\hline 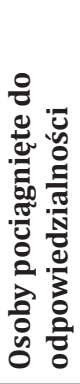 & 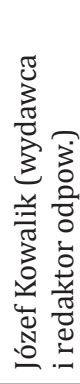 & 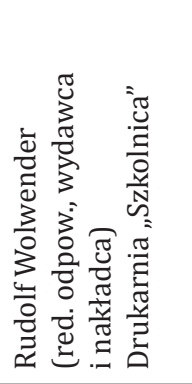 & 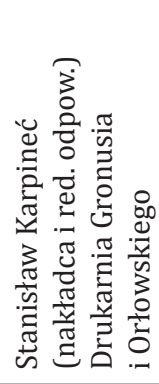 & 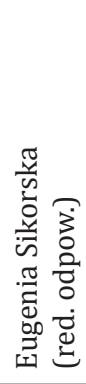 & 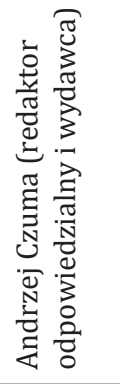 & 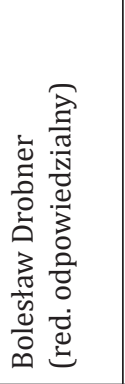 & 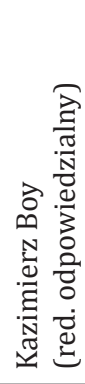 & 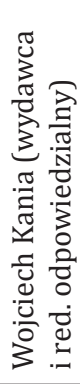 \\
\hline 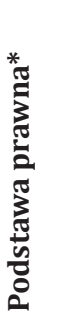 & 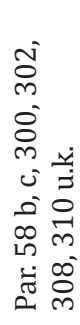 & 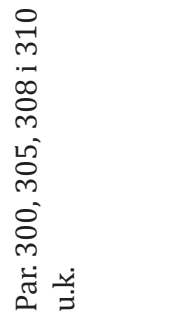 & 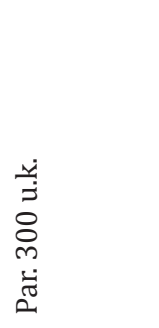 & 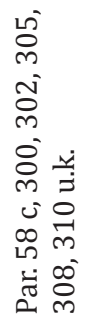 & 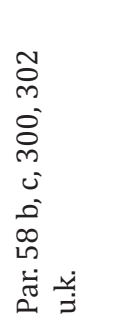 & 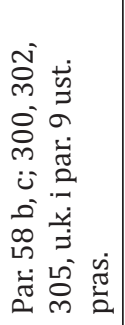 & 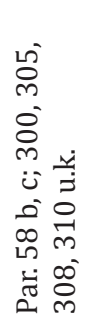 & 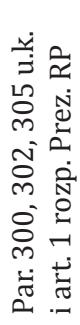 \\
\hline 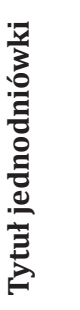 & 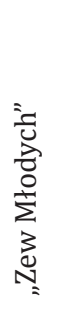 & 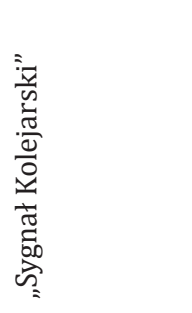 & 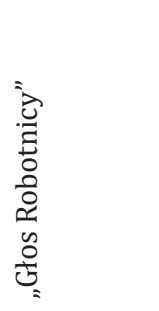 & 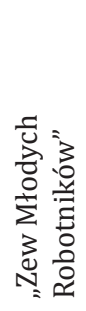 & 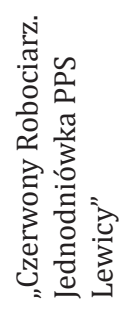 & 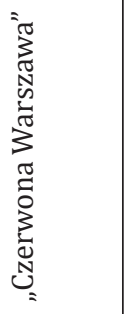 & 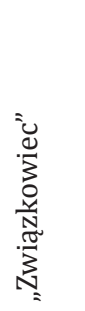 & 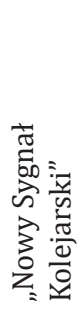 \\
\hline 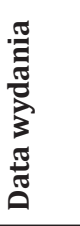 & 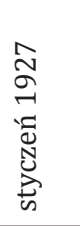 & 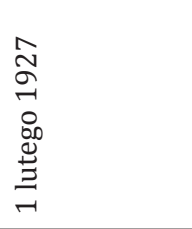 & 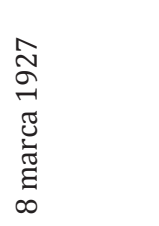 & 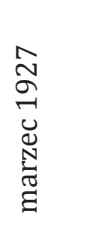 & 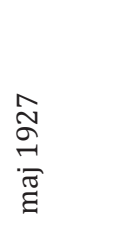 & 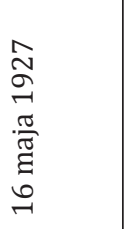 & 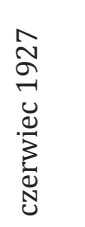 & 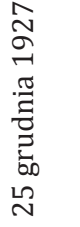 \\
\hline
\end{tabular}




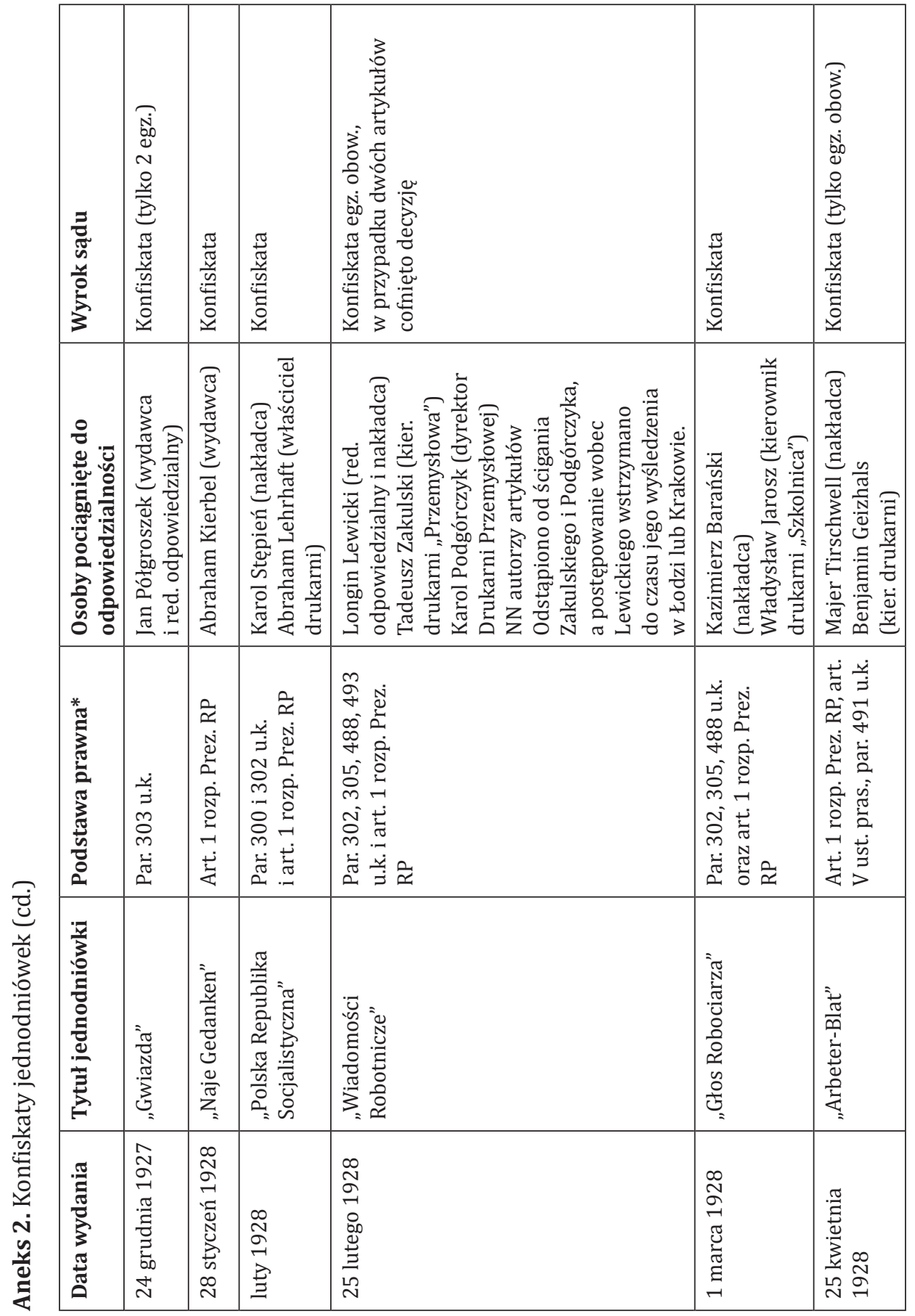


- [185]

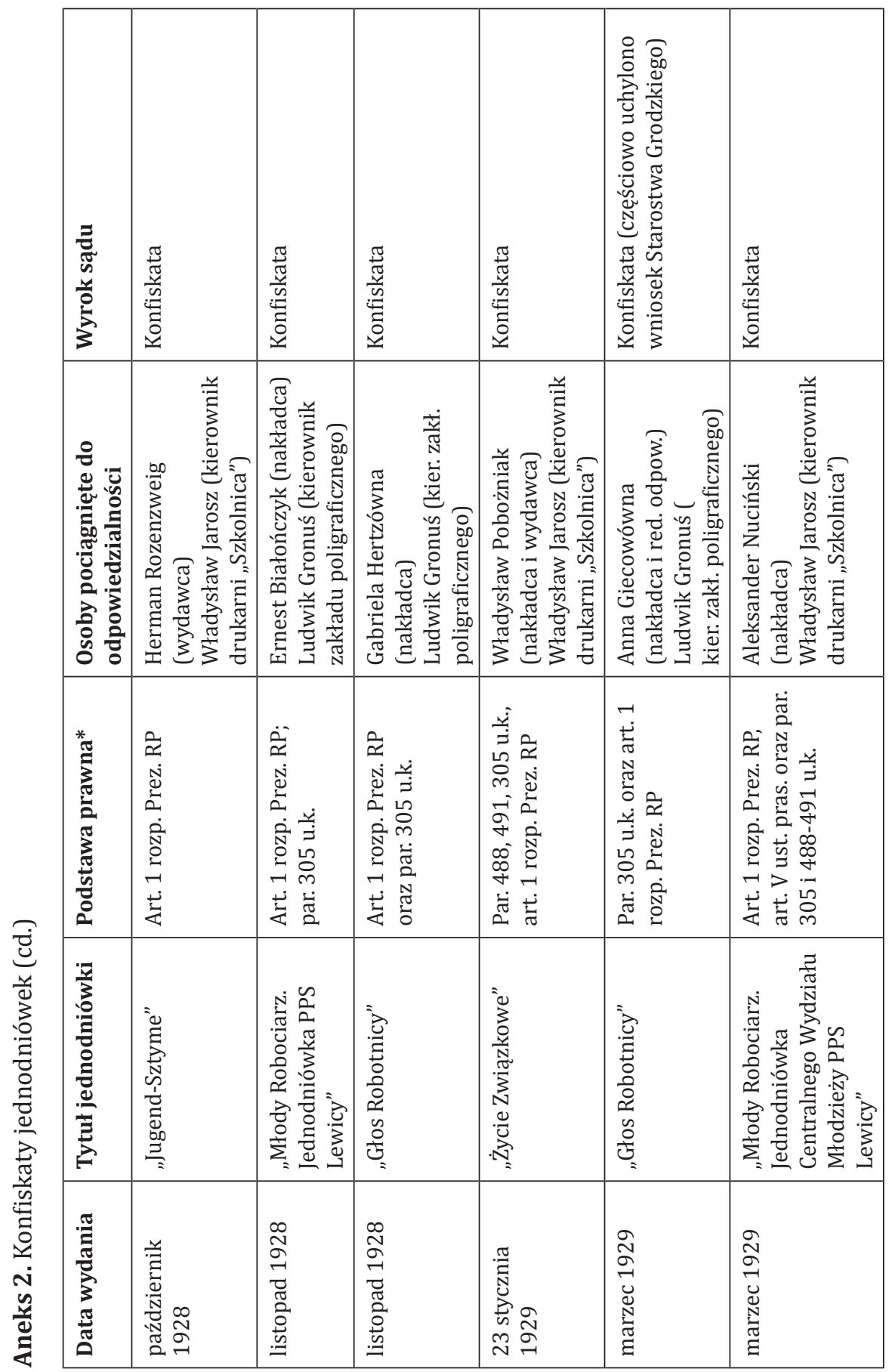




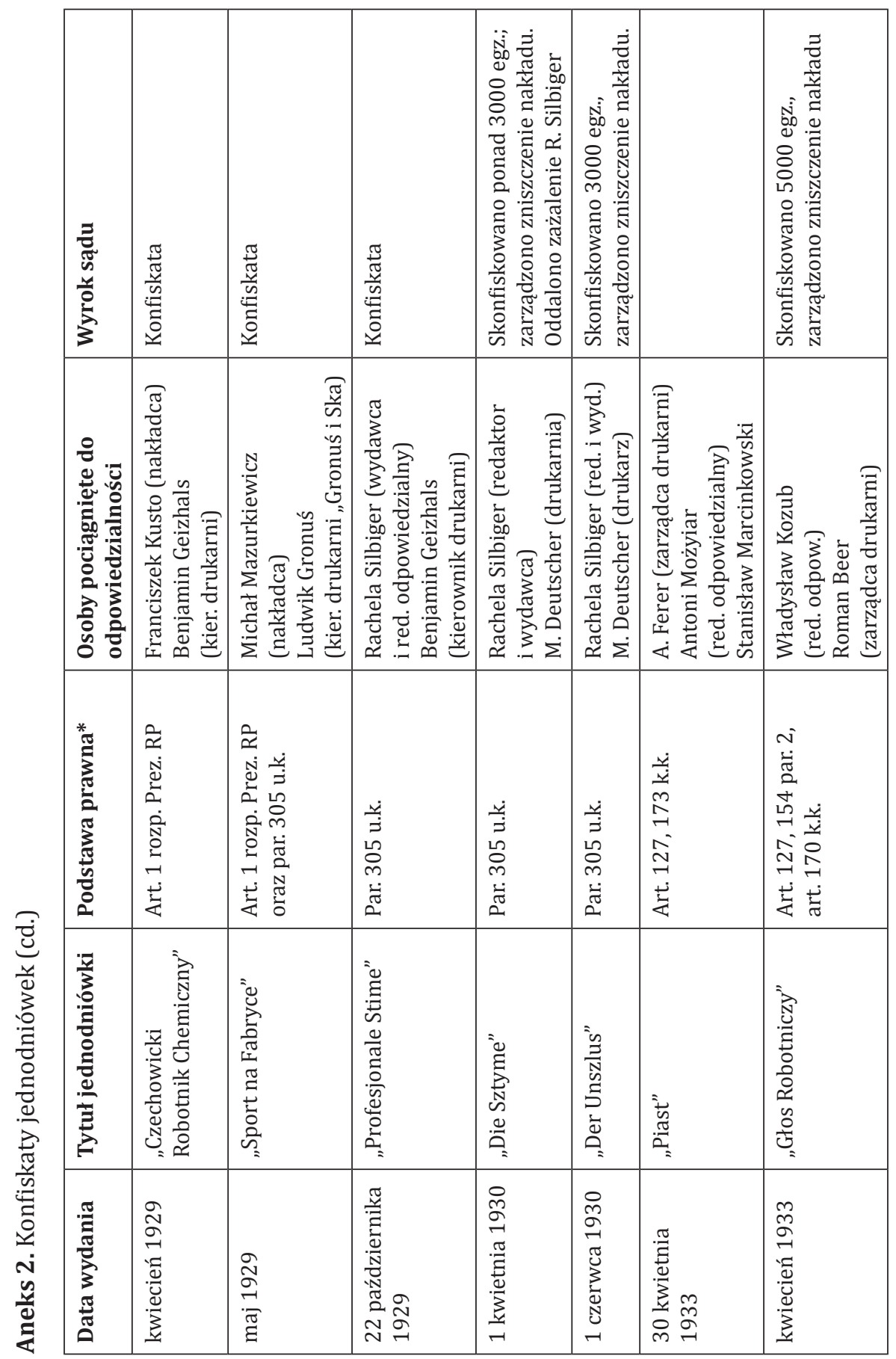


D [187]

\begin{tabular}{|c|c|c|c|c|c|c|}
\hline 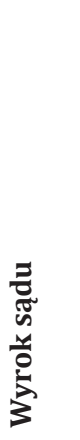 & 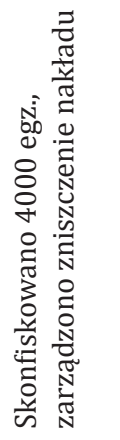 & 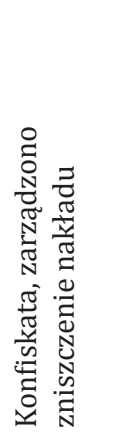 & 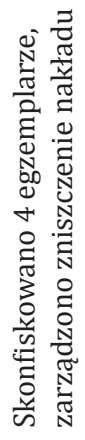 & 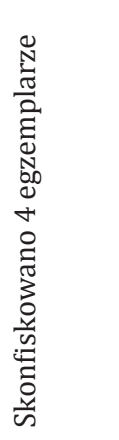 & 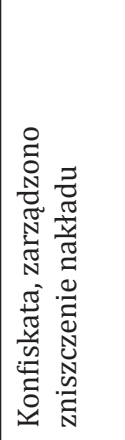 & 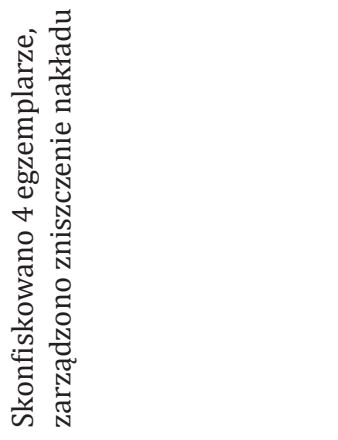 \\
\hline 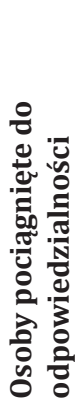 & 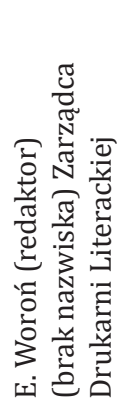 & 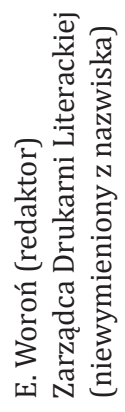 & 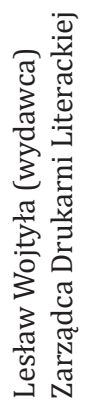 & 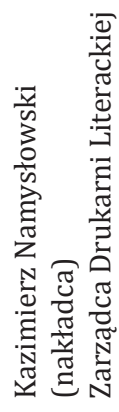 & & 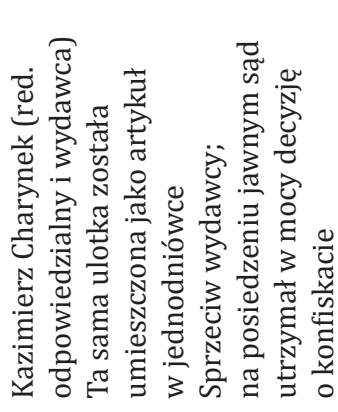 \\
\hline 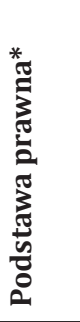 & 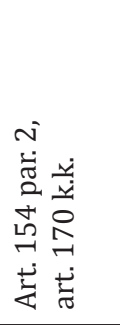 & 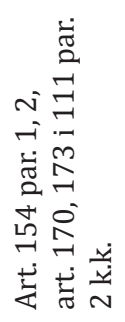 & 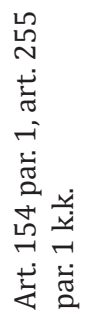 & 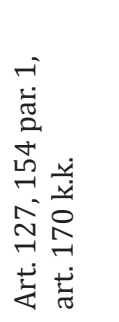 & 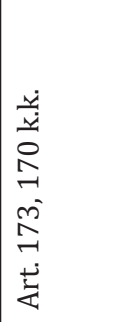 & 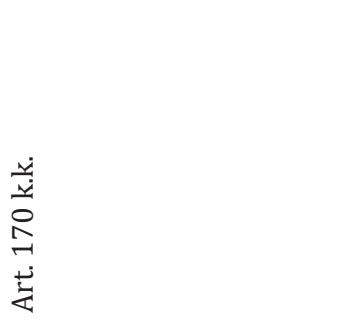 \\
\hline 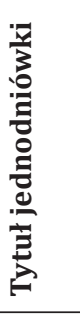 & 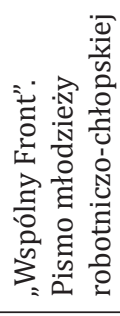 & 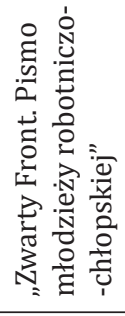 & $\frac{i y}{0}$ & 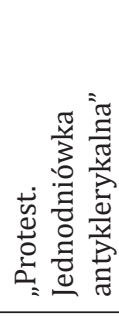 & 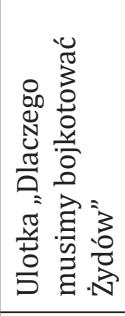 & 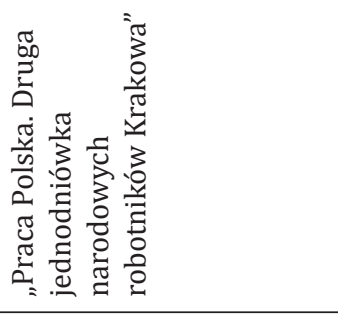 \\
\hline 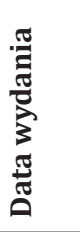 & 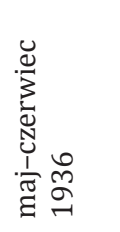 & 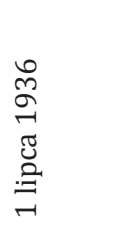 & 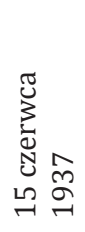 & $\stackrel{\hat{m}}{\stackrel{-}{\sim}}$ & 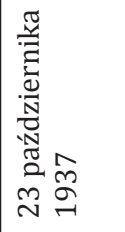 & 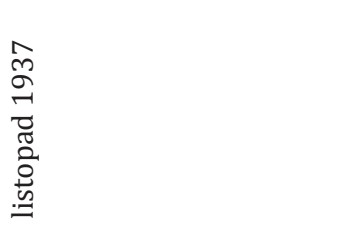 \\
\hline
\end{tabular}




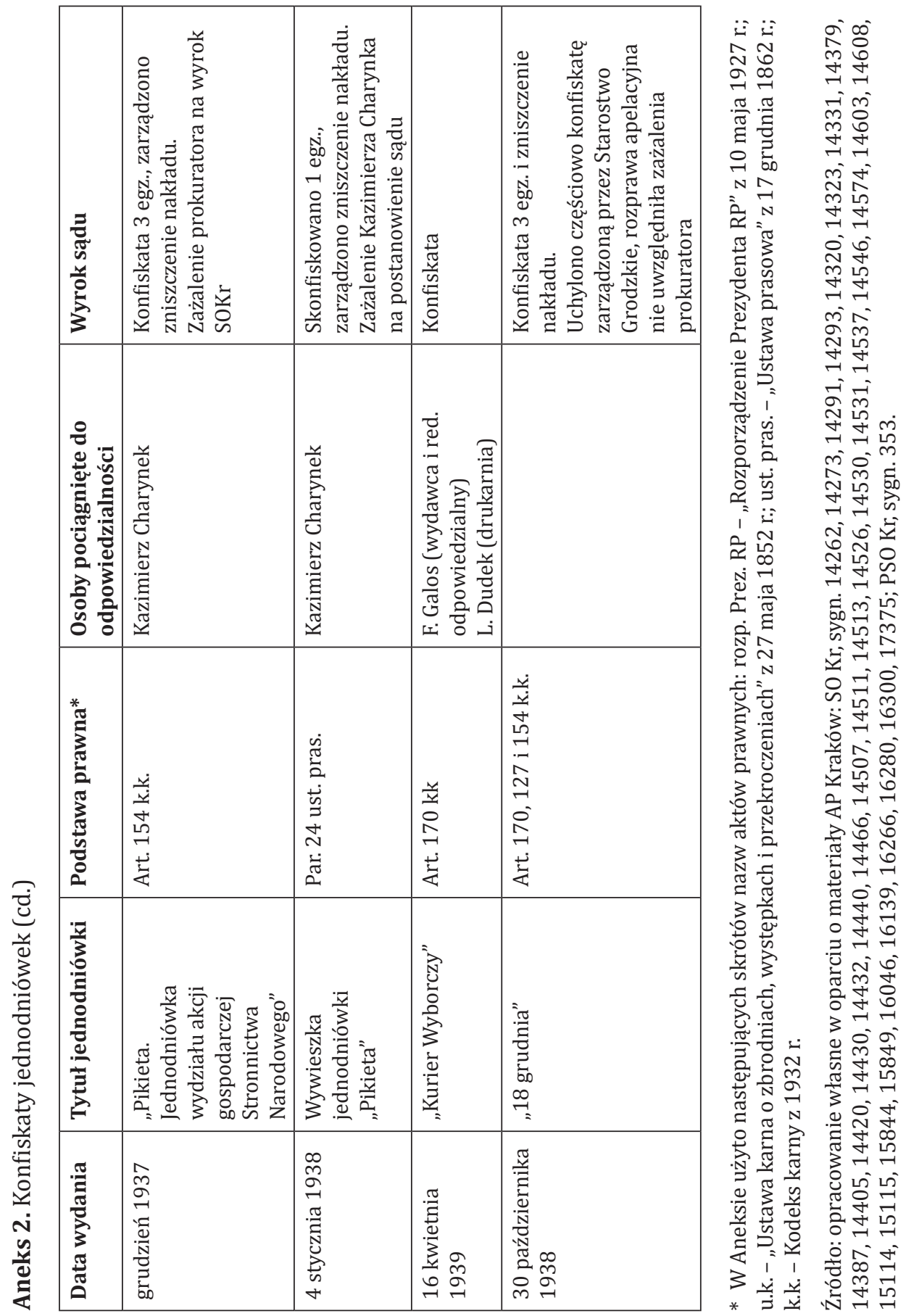

